\title{
USING ERP SYSTEM TO TEACH ACCOUNTING COURSES
}

\author{
Dr. Benjamin Bae \\ Professor \\ Department of Accounting and Finance \\ School of Business and Public Administration \\ California State University, Bakersfield, USA \\ E-mail: bbae@csub.edu \\ Dr. C. Christopher Lee \\ Professor \\ Department of Management and Organization \\ School of Business \\ Central Connecticut University, USA \\ E-mail: christopher.lee@ccsu.edu
}

Received: August 29, 2021 Accepted: September 10, 2021 Online Published: September 23, 2021

DOI: 10.46281/ijafr.v8i1.1352

URL: https://doi.org/10.46281/ijafr.v8i1.1352

\begin{abstract}
This paper discusses the use of Enterprise Resource Planning (ERP) systems as a teaching tool in Accounting Courses. Students can understand better the accounting cycle and business transaction processing by doing exercises and projects using the ERP system because it clearly shows the complete transaction cycle from the beginning to the end in a systematic and integrated way. Specifically, practical suggestions and usages in the class setting are illustrated based on the SAP system. This handson and active learning approach greatly enhances the learning of Accounting Courses such as financial and managerial accounting courses, finance courses, and information systems courses.
\end{abstract}

Keywords: Enterprise Resource Planning (ERP), SAP, Information Systems, Accounting Concept.

JEL Classification Codes: G2, M1, M4.

\section{Enterprise Resource Planning System (ERP)}

\section{INTRODUCTION}

Technology plays a key role in today's business environment. Many companies rely heavily on computers and the software that runs them to perform various business cycles. It is becoming more and more important for all businesses to look for solutions to data management in the field of information technology. One of the solutions is an Enterprise Resource Planning (ERP) System. An Enterprise Resource Planning System, or ERP, is a collection of software programs, which links all of an enterprise's various diverse business functions into one cohesive database. By linking together business functions such as finance, manufacturing, sales and human resources into one database, an enterprise is able to integrate its data in such a way that the data may be used by multiple users for various purposes at different locations. For example, an organization's ERP system would allow an employee in the credit department to check whether or not a customer with an outstanding balance has other orders currently 
in production or waiting in the warehouse and place a stop-shipment on the items, or a customer service employee can query to determine why a customer has not received the most recent order regardless of the current order status.

In addition, AAA 1986 (AAA, 1986) and AECC 1990 (AECC, 1990) reports all emphasize that information systems should be a fundamental part of accounting education. Traditionally, accounting has been taught by functional areas such as financial, managerial, tax, auditing and systems. This functional approach often brings some unexpected outcomes, such as a lack of integration among different functional areas coupled with a lack of integration of the information technology and application across the various functional areas.

ERP systems can help an organization automate core business systems. In addition, organizations often implement ERP systems as part of a reengineering project because ERP systems use existing best business practices to design business processes.

The major ERP system software companies include SAP, AG. And Oracle. SAP is considered the global market leader in ERP software. It is one of the most widely used ERP systems. Thus, the following examples of how the ERP systems are being effectively used in accounting courses are primarily based on the SAP system.

\section{THE ERP PROJECT'S POTENTIAL FOR ENHANCING ACCOUNTING CONCEPTS AND KNOWLEDGE}

As educators we want to make our accounting classes interesting and motivating. The ERP system can be used as a powerful teaching tool to encourage students to take responsibility in their learning. Togo and McNamee (1995) shows that computer use in accounting education increases interest in accounting.

ERP markets are growing continuously according to AMR Research (2001). Midsize companies have begun to purchase and install ERP software (Piturro, 1999). If this trend continues, most of large and midsize firms will have an ERP system operating in the near future. As ERP systems are becoming the major systems in the accounting and reporting cycles of companies, our accounting majors need to understand the systems. Furthermore, accounting educators have been mandated by professional bodies and employers to teach accounting students relevant information technology skills and knowledge (Boyce, 1999).

Considering these factors, it is imperative that students understand the ERP system and have hands-on experiences to some extent. With success, this active and hands-on learning approach can lead to better understanding of the accounting concepts and help the students retain knowledge and skills for future use.

The SAP R/3's design is based on the premise that an accounting system should be integrated, real-time, enterprise-wide, secure, and reliable. SAP R/3 has two main accounting modules, Financial Accounting (FI) and Controlling (CO). The main reporting purpose of FI is for external legal reporting to shareholders, creditors, and the public. The main reporting purpose of $\mathrm{CO}$ is for internal managerial reporting such as profit center accounting or profitability analysis.

\section{THE USE OF ERP SYSTEMS TO ILLUSTRATE ACCOUNTING CONCEPTS The Business/Accounting Cycle}

Financial and managerial accounting tools in SAP R/3 are contained in the financial accounting (FI) and controlling (CO) modules. The central task of $\mathrm{G} / \mathrm{L}$ accounting function in SAP is to provide a comprehensive picture of external accounting and accounts. Recording all business transactions in a software system that is fully integrated with all the other operational areas of a company ensures that the accounting data is complete and accurate. Additionally, the integration of the SAP R/3 modules of Investment Management (IM), Sales and Distribution (SD), Materials Management (MM), and Human Resources (HR) provide classroom instructors the ability to illustrate a more comprehensive business cycle. Using SAP in the classroom to illustrate the business/ accounting cycle can provide:

- An understanding Basic Navigation skills that apply not only to SAP R/3 but also other ERP Systems and Accounting Packages 
- An understanding the concept of Fiscal Years and posting periods

- Entering and Posting Journal Entries including accounts payable vouchers and sales invoices

- Monthly G/L Closing

- Generating Balance Sheets

- Generating Product Period and Year to Date Income Statements

- An understanding the relationship between Inventory, Purchasing, A/P and G/L accounting by going through the purchasing cycle

- An understanding the relationship between Inventory, Sales, Accounts Receivable, and General Ledger Accounting

\section{Application of Basic Cost Accounting Principles in the ERP System}

Management accounting tools in SAP R/3 are contained in the controlling (CO) and enterprise controlling (EC) modules. These tools include cost center accounting, internal orders, product costing, activity based costing, profitability analysis and profit center accounting. These two SAP modules can be used in the classroom to illustrate the following cost accounting principles:

- Analyzing an organizations overhead costs according to where they were incurred within the organization. Planning, collecting, and settling costs of organizations internal jobs and tasks.

- Developing different types of cost estimates for a particular product or subassembly, such as standard cost, future cost, tax cost, or commercial cost estimate.

- Planning the cost of products before an order to commence manufacturing is placed.

- Assigning costs incurred in an organization to the activity units within the organization.

- Activity-Based Costing.

- Evaluating profit or contribution margin based on an organization's market segments. These market segments can be classified according to products, customers, orders or any combination of these, or strategic business units, such as sales organizations or business areas, with respect to an organization's profit or contribution margin.

- Working with two different types of cost drivers, activity types and statistical key figures.

- Understanding the differences of primary cost elements, primary revenue elements, and secondary cost elements.

\section{Examples of Cost Accounting Principles Using SAP}

- Set up a standard hierarchy (the standard hierarchy is the central cost center hierarchy created in your system and acts as the one repository for all cost centers). This is done through SAP standard menu $\rightarrow$ accounting $\rightarrow$ controlling $\rightarrow$ cost center accounting $\rightarrow$ master data $\rightarrow$ standard hierarchy $\rightarrow$ display (transaction code: OKENN). Enter the controlling area and click the enter button $\rightarrow$ 2000. Find H3000 for Company 3000 - USA and click the arrow to the left of the cost center. Click on the details button to expand the section of the window where the details for cost center groups are displayed. Once the cost center groups are displayed, click on the expand arrow in front of H3400 Technical Services and click on the expand arrow in front of H3410 Technical Services to obtain all of the cost centers for H3410 Technical Services.

\section{- Create New Cost Centers}

Creating new cost centers can be done through SAP standard menu $\rightarrow$ accounting $\rightarrow$ controlling $\rightarrow$ cost center accounting $\rightarrow$ master data $\rightarrow$ cost center $\rightarrow$ individual processing $\rightarrow$ create (transaction code: KS01). Complete the screen information by filling in the cost center number and valid transaction dates where necessary. Enter all of the required data. The required data is any field that shows a box with a checkmark on the left side of the screen. If the cost center has been set up correctly you will receive a message in the status bar stating the cost center has been created. Repeat this step for each cost center which is to be created. 
- Review a Cost Center Report that Shows a Comparison of Planned Costs vs. Actual Costs for a Specified Cost Center Period

Start with the SAP standard menu $\rightarrow$ accounting $\rightarrow$ controlling $\rightarrow$ cost center accounting $\rightarrow$ information system $\rightarrow$ reports for cost center accounting $\rightarrow$ plan/ actual comparisons $\rightarrow$ cost centers: actual/plan/variance (transaction code: S_ALR_87013611). Complete the initial screen by filling in the controlling area and fiscal year. Import the report into a spreadsheet program (i.e. MS Excel) by using the office Integration button. The report will be displayed in SAP as a spreadsheet and may also be saved in spreadsheet form by going to File $\rightarrow$ Save Copy As.

- Record Transactions in the FI Module

Beginning with the SAP standard menu $\rightarrow$ accounting $\rightarrow$ general ledger $\rightarrow$ document entry $\rightarrow$ $\mathrm{G} / \mathrm{L}$ account posting (transaction code: FB50). Enter the document date, and record the journal entry information in the items section of the screen. When all of the line items are entered correctly there will be a green light in the SAP R/3 "Traffic Light" box and a document number will be displayed in the status bar. The generation of the document number completes the transaction recording task.

\section{- Review Posting Transactions}

Using the SAP standard menu go to accounting $\rightarrow$ controlling cost center $\rightarrow$ cost center accounting $\rightarrow$ information system $\rightarrow$ plan/ actual comparisons $\rightarrow$ cost centers: actual/ plan/ variance (transaction code: S_ALR_87013611). On the display screen enter the controlling area, fiscal year, periods, and plan version. The variance report will be displayed in SAP R/3 as a spreadsheet report. Scroll down to view the origin of a line item by double clicking on the line item. A popup screen listing will be displayed, choose the desired report and double click the line item.

\section{Designing an Accounting Information System}

Accounting information systems gather, collect, verify and process data/transactions throughout the entire organization and generate basic financial reports such as balance sheet, income statement, and statement of cash flows. In order to generate financial reports, accounting information systems must be designed such that all the journal entries can be entered with proper account codes, account titles, cutoff dates, and responsible units to be charged, and so on. Financial accounting, controlling, and enterprise controlling modules can be used to set up the necessary configurations and formats for generation of the financial information. The following operations are conducted to design and customize the organization's financial information needs and requirements:

- Setting up a chart of accounts

- Setting up a Fiscal Year

- Setting up an organizational structure

- Setting up $\mathrm{G} / \mathrm{L}$ accounting information

- Understanding of the importance of setting reconciliation accounts so that information such as Accounts Receivable, Accounts Payable, and Inventory post to the correct General Ledger Account.

Appendix A provides a copy of the SAP project which can be used in financial and managerial accounting and accounting information systems courses. The project is important to ensure that students are able to apply the accounting concepts to the ERP system. It provides an opportunity to ensure students are able to learn by using the actual system.

Appendix B provides all the basic menu paths and commands necessary to complete the project. Students can acquaint themselves with the system following the instructions. It contains most of menus, commands, and operational instructions for the completion of the project.

Overall, the project is designed to acquaint students with some of the internal control and system issues as well as ERP technologies that will prove useful to them in their careers. 


\section{Students' Assessment}

\section{CONCLUSIONS}

Student's assessment or response to the ERP project is usually either extremely positive or extremely negative. Initially, the ERP project seems to overwhelm the students because it looks like a tremendous challenge to them. This is mainly due to the complexity of the SAP system and the various tasks required in the project. However, most students show a lot of interest in the project because they know that learning the ERP system will advance their opportunities for future employment, especially since a larger number of companies are in the process of implementing ERP systems. These students appear to understand that the knowledge and experience gained by the ERP project, SAP in this case, will grant them a competitive advantage over the students who have not had any exposure to these systems.

Typically, undergraduate students with no job experience are very apprehensive toward the project and may view it as another obstacle for them to complete prior to graduation. However, once these students complete the project, their view seems to change to a more positive view and they are able to see the ERP project as part of the life long learning associated with a successful accounting career. Only those students who have not reached the point in which they can see through what the system can do and help them in various ways remain negative even after the completion of the project. Students' evaluations, emails and letters indicate that most of them appreciate learning both the technicalities of an ERP system as well as the enhancement of their accounting knowledge.

This paper demonstrates how the ERP system has been used in accounting courses such as financial and managerial accounting and accounting information systems courses. The use of the SAP system in class helps students to learn the accounting principles and concepts by going through processing steps of the business/accounting transactions and preparing financial and managerial reports. Students can clearly understand the accounting cycle by processing the transactions and grasp the interrelationship of the issues involved in the process. This active and hands-on approach can greatly facilitate the learning process and enhance the learning of financial and managerial accounting principles as well as accounting information systems concepts.

\section{REFERENCES}

American Accounting Association (AAA). (1986). Future Accounting Education: Preparing for the Expanding Profession. Committee on the Future Structure, Content, and Scope of Accounting Education (The Bedford Committee). Issues in Accounting Education (Spring), 168-195.

Accounting Education Change Commission (AECC). (1990). Position Statement No. 1: Objective of Education for Accountants. Issues in Accounting Education, 5, 307-312.

AMR Research. (2001). AMR Research Predicts ECM Market for Applications and Services Will Grow to $\$ 264$ Billion by 2005 , Press Releases.

Boyce, G. (1999). Computer-assisted teaching and learning in accounting: pedagogy or product?. Journal of Accounting Education, 17(2-3), 191-220.

Piturro, M. (1999). How midsize companies are buying ERP. Journal of accountancy, 188(3), 41.

Togo, D. F., \& McNamee, A. H. (1995). Computer integration into the accounting curriculum: Learning benefits, problems, and guidelines. Journal of Accounting Education, 13(2), 149-158.

\section{Copyrights}

Copyright for this article is retained by the author(s), with first publication rights granted to the journal. This is an open-access article distributed under the terms and conditions of the Creative Commons Attribution license (https://creativecommons.org/licenses/by/4.0). 